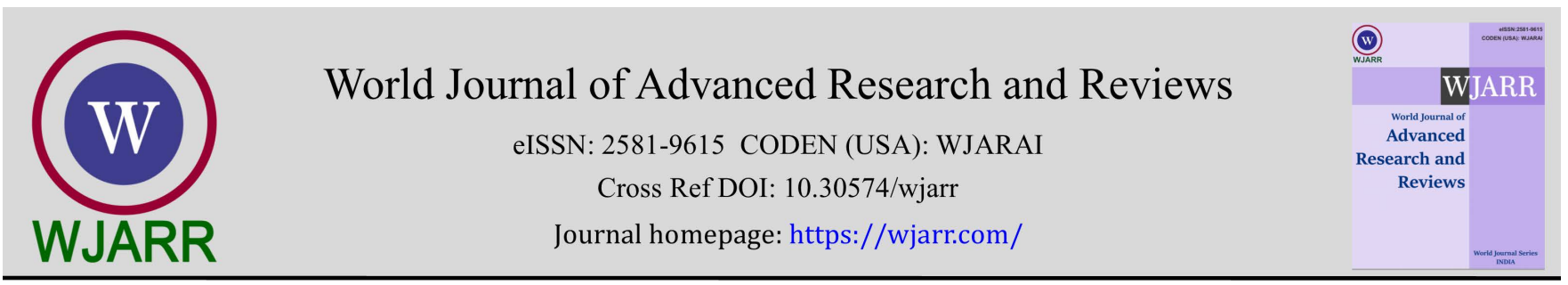

(RESEARCH ARTiClE)

Check for updates

\title{
Comparison of cognitive and emotional schema in women with and without marital satisfaction
}

\author{
Zahra Pouresmaili Najafabadi ${ }^{1}$, Neda Alibeigi ${ }^{2,}{ }^{*}$ and Elnaz Eskandarnia ${ }^{3}$ \\ ${ }^{1}$ Department of Clinical Psychology, Islamic Azad University, science and research branch, Tehran, Iran. \\ 2 Psychosis Research Center, Department of Psychiatry, Assistant professor, University of Social Welfare and Rehabilitation \\ Sciences, Tehran, Iran. \\ ${ }^{3}$ Clinical Psychologist, Medical University of Mashhad. Mashhad. Iran.
}

World Journal of Advanced Research and Reviews, 2021, 12 (01), 056-065

Publication history: Received on 14 August 2021; revised on 26 September 2021; accepted on 28 September 2021

Article DOI: https://doi.org/10.30574/wjarr.2021.12.1.0455

\begin{abstract}
Objectives: Various factors are effective in dissatisfaction and marital conflicts. Schemas play an important role in behavior and relationships. This study examined the role of cognitive and emotional schemes in women's marital satisfaction.

Methods: This study was a cross sectional research and the population consists of all married women 20-55 years old in Tehran. 100 women were selected using stratified random sampling in categories of housewives and employed and place of living and completed questionnaires. The assessment tools included The Young's early maladaptive Schema Short Form (YSQ-SF), Leahy Emotional Schemas (LESS) and Enrich Marital Satisfaction questionnaire. Women with and without marital satisfaction were separated based on $t$ score obtained from the ENRICH questionnaire.

Results: Findings showed no significant differences in demographic data for women with and without marital satisfaction $(\mathrm{P}<0.05)$. Results of independent $t$ test and Mann-Whitney showed that women with and without marital satisfaction are different in all schemas except schemas of sacrifice and unrelenting standards and schemas of control, blame, comprehensibility, acceptance of feelings, consensus, validation and higher values of emotional schemas (P $<0.05)$.The regression analysis showed Abandonment schema and unrelenting standards schema and schema of guilt and validation of emotional schemas can predict marital satisfaction $(\mathrm{P}<0.05)$. And schemas guilt, blame, emotional deprivation and unrelenting standards simultaneously correlated with marital satisfaction $(\mathrm{P}<0.05)$.
\end{abstract}

Conclusion: The formation and development of cognitive and emotional schemas during life can influence various aspects of married life. So that these schemas have an important role in evaluation of emotional partner and attitude toward them.

Keywords: Early Maladaptive Schemas; Emotional Schemas; Cognitive Schema; Marital Satisfaction

\section{Introduction}

Marital Satisfaction is a personal cognitive and emotional assessment about marital relationship [1].Emphasis on marital satisfaction due to its role on mental health of couples and their children is inevitable [2]. Data of divorces are the most reliable indicator of marital turmoil [3], shows that marital satisfaction is not easy to achieve [4]. Epstein and Bacaum (2002) suggest that many cognitive factors are effective in dissatisfaction and marital conflicts [5]. Some kind

\footnotetext{
* Corresponding author: Neda Alibeigi

Psychosis Research Center, Department of Psychiatry, Assistant professor, University of Social Welfare and Rehabilitation Sciences,Tehran, Iran.
}

Copyright (C) 2021 Author (s) retain the copyright of this article. This article is published under the terms of the Creative Commons Attribution Liscense 4.0. 
of cognitions that are important in the marital relationship, are schemas.Schemas may influence development of chronicity or severity of emotional and affective disorders [6-8].

Emotions play an important role in various aspects of life such as adaptation to life changes and stressful events [9].

Leahy (2002) based on the concept of emotional processing and emotions inspired by the Meta model, offered emotional schemas model [10]. Research shows that emotional schemas are associated with several psychiatric disorders including anxiety, depression, alcohol abuse, post-traumatic stress disorder, marital conflicts and personality disorders [11]. Some researches have shown intolerance in mixed emotion has an important role on marital satisfaction [12]. Individuals with marital conflicts report low emotion expression and validation and high score on shame and intolerance more than satisfied ones [12]. Researchers suggest the idea of relation between marital satisfaction and emotional schema in different levels [13]. Pirsaghi, Mohammad Nazari, Naim and Shafa (2015) showed marital conflict is associated with mature and immature defense mechanisms and emotional schemas but they didn't study any of the schemas separately [14]. The results of Yousefi, Abedin, Tirgari and Fathabadi study (2010) showed that by increasing the presence of maladaptive schemas, marital satisfaction and intimacy reduced [2]. Hasanvand, Davoodi and valizadeh (2010) concluded there were relationship between some subscales of early maladaptive schemas and marital satisfaction [15]. In the present study with respect to this belief that early maladaptive schemas can be the core of many personality disorders and interpersonal problems - and the most important inter personal relationship in the context of human society is marriage - and growing up of children and the next generation of society occur in family, authors aimed to define the role of cognitive and emotional schemas on marital satisfaction. Researches on marital interactions show that individuals are different in ability of understanding emotions.

There are many researches on early maladaptive schema but few research work on emotional schema and their relation with marital satisfaction. There is correlation between early maladaptive schema and emotional schema but we don't know which of them can predict marital satisfaction more? And which specific schema is more related to marital satisfaction/dissatisfaction. Finding the relation and portion of variances play an important role on educational and psychological intervention programs.

\section{Methods}

This study was ex post facto research and the population consists of all married women 20-55 years old in Tehran. The sample size based on Anastasi studies for causal-comparative study is considered 100 subjects [16] that were selected by stratified random sampling. Considering the possibility of error in completion of questionnaires 52 participants selected for each group. Criteria for classification was satisfaction/dissatisfaction. 52 women with marital satisfaction and 52 women with marital dissatisfaction. For sampling Tehran divided to five sections: north, south, east, west and center. Randomly we selected center of Tehran and from regions in center, region 7 of municipality randomly selected. On the basis of previous research and the role of employment/unemployment, we considered two categories: housewives and employees, and then employment divided to government employees, private employees and selfemployed. For employed ones selected 3 place with referring to several government agencies, including the Ministry of Interior and the Bureau of Women's Affairs municipalities and private companies (easy to pay, Ryan khatam and the Department of Paresh). For selection of Housewives, mothers of children who were studying in Hasheminejad school as well as people who were referred for shopping to Yas shopping center and were housewives randomly selected. Sampling continued until the number of samples in both satisfied women and dissatisfied women completed.

\section{Instruments}

Young's Schema Questionnaire (YSQ-SF), Leahy's Emotional Schema Scale (LESS) and Enrich Marital Satisfaction Questionnaire were used.

\subsection{Young Schema Questionnaire- Short Form}

This 75 items questionnaire measure 15 maladaptive schemas [17]. In the Short form, each schema is measured by five questions, and classify 15 maladaptive schemas into 5 areas. These schemas include:

\subsubsection{Disconnection/Rejection}

It includes 5 schemas: Abandonment/Instability, Mistrust/Abuse, Emotional Deprivation, Defectiveness/Shame and Social Isolation/Alienation 


\subsubsection{Impaired Autonomy and/or Performance}

It includes 4 schemas: Dependence/Incompetence, Vulnerability to Harm or Illness, Enmeshment/Undeveloped Self and Failure

\subsubsection{Impaired Limits}

It includes 2 schemas: Entitlement/Grandiosity, Insufficient Self-Control and/or Self-Discipline

\subsubsection{Other-Directedness}

It includes 3 schemas: Subjugation, Self-Sacrifice and Approval-Seeking/Recognition-Seeking

\subsubsection{Over vigilance/Inhibition}

It includes 4 schemas: Negativity/Pessimism, Emotional Inhibition, Unrelenting Standards/Hyper criticalness and Punitiveness

Schmidt, Joiner, Young \& Telch, (1995) reported alpha coefficient 0.83 (for Enmeshment/Undeveloped Self schema) to 0.97 (for defectiveness / shame) for subscales in normal population [18]. Test-retest reliability was between 0.50 to 0.82. Aahi (2005) has translated and standard this questionnaire in Iran and reported 0.98 Cronbach's alpha in men and 0.97in women [19].

\subsection{Leahy Emotional Schema Scale}

Leahy emotional schemas scale is a 50-items scale using 5 point Likert scale. Persian version of this scale has been prepared by Khanzadeh, Edrisi, Mohamadkhani and Saeidian ,2011[20]. The results of exploratory factor analysis showed that from 16 extracted factors of this scale, 12 factors are coordinated with the Leahy Emotional Schemas. These schemas include: Rumination, Guilt, Comprehensibility, Control, Numbness, Duration, Expressing emotions, Higher Values, Consensus, Simplistic View of Emotion, Validation, Acceptance of Feelings, Blame and Expression. Reliability of this scale through a two-week test-retest method for the total scale was 0.78 . Also internal consistency coefficient of the scale using Cronbach's alpha for the total scale was 0.82 [20]. Persian version with 37 items was used in this study.

\subsection{Enrich Marital Satisfaction Questionnaire (ENRICH)}

47-items form used in this study. This scale, measures satisfaction and compliance individuals with nine aspects of the partnership include: personality issues, marital communication, conflict resolution, financial management, leisure activities, sexual relationships, marriage and children, relatives and friends and religious orientation. The 47-item form is scored on a 5-degree scale. The validity of 47-statement form reported 0.92 using Cronbach's alpha coefficient. Soleimanian (1994) for the first time in Iran assessed internal consistency and reported 0.95 for long form and it was 0.93 in short form [21]. Mahdavian (1997) in his review about the validity of Enrich test using Pearson correlation coefficient and test-retest (within a week), validated test for men 0.93 and 0.94 for women and 0.94 for men and women [22].

To carry out research, questionnaires were amplified and then referred to centers included in the sampling. The number of samples required from each center was randomly selected and questionnaires were given to them. Participation in research was voluntarily and they were asked to fill the anonymous questionnaires if they were interested. There was no need for identifying data and confidentiality were considered.

\section{Results}

58 percent of participants in this study were between 20 and 30 years, $27 \%$ between 30 and 40 years, $12 \%$ between 40 and 50 years and only $3 \%$ were above 50 years.14 percent of participants were high school graduates, $48 \%$ were B. A or B.SC and 38\% were M. A or M.SC and higher. 27 percent of participants were housewives and 73 percent were employees (26 percent governmental employees, $24 \%$ private and $23 \%$ self-employed employees). 48questionnaires were completed correctly in dissatisfied women and 52 questionnaires in satisfied ones. To study the difference between two groups in cognitive and emotional schemas, Kolmogrov Smirnov test two independent samples t-tests were used for normal variables and U Mann-Whitney test was used for non-parametric abnormal variables. 
Table 1 independent t test for comparison of mean of cognitive schemas in women with marital satisfaction and without marital satisfaction

\begin{tabular}{|c|c|c|c|c|c|c|c|c|}
\hline & & \multirow[t]{2}{*}{ Mean } & \multirow[t]{2}{*}{$\begin{array}{l}\text { Standard } \\
\text { deviation }\end{array}$} & \multicolumn{2}{|c|}{$\begin{array}{l}\text { Levin test } \\
\text { variances }\end{array}$} & \multirow[t]{2}{*}{$\mathbf{T}$} & \multirow{2}{*}{$\begin{array}{l}\text { Degree } \\
\text { of } \\
\text { freedom }\end{array}$} & \multirow[t]{2}{*}{$\begin{array}{l}\text { Significance } \\
\text { level }\end{array}$} \\
\hline & & & & $\mathbf{F}$ & $\begin{array}{l}\text { Significance } \\
\text { level }\end{array}$ & & & \\
\hline \multirow[t]{2}{*}{ Abandonment/Instability } & $\begin{array}{l}\text { With } \\
\text { satisfaction }\end{array}$ & 10.90 & 4.564 & \multirow[t]{2}{*}{0.983} & \multirow[t]{2}{*}{0.128} & \multirow[t]{2}{*}{3.490} & \multirow[t]{2}{*}{93.878} & \multirow[t]{2}{*}{0.001} \\
\hline & $\begin{array}{l}\text { Without } \\
\text { satisfaction }\end{array}$ & 14.31 & 5.199 & & & & & \\
\hline \multirow[t]{2}{*}{ Self-Sacrifice } & $\begin{array}{l}\text { With } \\
\text { satisfaction }\end{array}$ & 16.62 & 4.963 & \multirow[t]{2}{*}{0.488} & \multirow[t]{2}{*}{0.505} & \multirow[t]{2}{*}{0.880} & \multirow[t]{2}{*}{95.784} & \multirow[t]{2}{*}{0.381} \\
\hline & $\begin{array}{l}\text { Without } \\
\text { satisfaction }\end{array}$ & 17.52 & 5.332 & & & & & \\
\hline \multirow[t]{2}{*}{ Unrelenting Standards } & $\begin{array}{l}\text { With } \\
\text { satisfaction }\end{array}$ & 17.04 & 4.732 & \multirow[t]{2}{*}{0.680} & \multirow[t]{2}{*}{0.412} & \multirow[t]{2}{*}{0.389} & \multirow[t]{2}{*}{93.190} & \multirow[t]{2}{*}{0.168} \\
\hline & $\begin{array}{l}\text { Without } \\
\text { satisfaction }\end{array}$ & 18.46 & 5.489 & & & & & \\
\hline \multirow[t]{2}{*}{ Entitlement/Grandiosity } & $\begin{array}{l}\text { With } \\
\text { satisfaction }\end{array}$ & 12.85 & 4.170 & \multirow[t]{2}{*}{.843} & \multirow[t]{2}{*}{.361} & \multirow[t]{2}{*}{3.144} & \multirow[t]{2}{*}{94.965} & \multirow[t]{2}{*}{0.002} \\
\hline & $\begin{array}{l}\text { Without } \\
\text { satisfaction }\end{array}$ & 12.85 & 4.170 & & & & & \\
\hline \multirow[t]{2}{*}{$\begin{array}{l}\text { Insufficient Self-Control } \\
\text { and/or Self-Discipline }\end{array}$} & $\begin{array}{l}\text { With } \\
\text { satisfaction }\end{array}$ & 11.56 & 4.070 & 4.575 & \multirow[t]{2}{*}{.035} & \multirow[t]{2}{*}{2.369} & \multirow[t]{2}{*}{87.121} & \multirow[t]{2}{*}{0.21} \\
\hline & $\begin{array}{l}\text { Without } \\
\text { satisfaction }\end{array}$ & 13.81 & 5.402 & 13.81 & & & & \\
\hline
\end{tabular}

Table 2 Mann-Whitney U Test Comparison of cognitive schemas means in women with marital satisfaction and without marital satisfaction

\begin{tabular}{|c|c|c|c|c|c|c|}
\hline & Group & Frequency & Mean & $\begin{array}{l}\text { U Mann } \\
\text { Whitney }\end{array}$ & Statistics & $\begin{array}{l}\text { Significance } \\
\text { level }\end{array}$ \\
\hline \multirow[t]{2}{*}{ Emotional deprivation } & With satisfaction & 52 & 42.07 & \multirow[t]{2}{*}{809.5} & \multirow[t]{2}{*}{-3.068} & \multirow[t]{2}{*}{0.002} \\
\hline & $\begin{array}{l}\text { Without } \\
\text { satisfaction }\end{array}$ & 48 & 59.64 & & & \\
\hline \multirow[t]{2}{*}{ Mistrust/Abuse } & With satisfaction & 52 & 43.59 & \multirow[t]{2}{*}{888.5} & \multirow[t]{2}{*}{-2.492} & \multirow[t]{2}{*}{0.013} \\
\hline & $\begin{array}{l}\text { Without } \\
\text { satisfaction }\end{array}$ & 48 & 57.99 & & & \\
\hline \multirow[t]{2}{*}{ Social Isolation/Alienation } & With satisfaction & 52 & 45.12 & \multirow[t]{2}{*}{968} & \multirow[t]{2}{*}{-1.962} & \multirow[t]{2}{*}{0.05} \\
\hline & $\begin{array}{l}\text { Without } \\
\text { satisfaction }\end{array}$ & 48 & 56.33 & & & \\
\hline \multirow[t]{2}{*}{ Defectiveness/Shame } & With satisfaction & 52 & 42.65 & \multirow[t]{2}{*}{840} & \multirow[t]{2}{*}{-2.989} & \multirow[t]{2}{*}{0.03} \\
\hline & $\begin{array}{l}\text { Without } \\
\text { satisfaction }\end{array}$ & 48 & 59 & & & \\
\hline
\end{tabular}




\begin{tabular}{|c|c|c|c|c|c|c|}
\hline \multirow[t]{2}{*}{ Failure } & With satisfaction & 52 & 39.22 & \multirow[t]{2}{*}{661.5} & \multirow[t]{2}{*}{-4.135} & \multirow[t]{2}{*}{0.000} \\
\hline & $\begin{array}{l}\text { Without } \\
\text { satisfaction }\end{array}$ & 48 & 62.72 & & & \\
\hline \multirow[t]{2}{*}{ Dependence/Incompetence } & With satisfaction & 52 & 41.03 & \multirow[t]{2}{*}{755.5} & \multirow[t]{2}{*}{-3.506} & \multirow[t]{2}{*}{0.000} \\
\hline & $\begin{array}{l}\text { Without } \\
\text { satisfaction }\end{array}$ & 48 & 60.76 & & & \\
\hline \multirow{2}{*}{$\begin{array}{l}\text { Vulnerability to Harm or } \\
\text { Illness }\end{array}$} & With satisfaction & 52 & 40.94 & \multirow[t]{2}{*}{751} & \multirow[t]{2}{*}{-3.941} & \multirow[t]{2}{*}{0.000} \\
\hline & $\begin{array}{l}\text { Without } \\
\text { satisfaction }\end{array}$ & 48 & 60.85 & & & \\
\hline \multirow{2}{*}{$\begin{array}{l}\text { Enmeshment/Undeveloped } \\
\text { Self }\end{array}$} & With satisfaction & 52 & 42.12 & \multirow[t]{2}{*}{812} & \multirow[t]{2}{*}{-3.038} & \multirow[t]{2}{*}{0.002} \\
\hline & $\begin{array}{l}\text { Without } \\
\text { satisfaction }\end{array}$ & 48 & 59.58 & & & \\
\hline \multirow[t]{2}{*}{ Punitiveness } & With satisfaction & 52 & 38.83 & \multirow[t]{2}{*}{641} & \multirow[t]{2}{*}{-4.123} & \multirow[t]{2}{*}{0.000} \\
\hline & $\begin{array}{l}\text { Without } \\
\text { satisfaction }\end{array}$ & 48 & 63.15 & & & \\
\hline \multirow[t]{2}{*}{ Emotional Inhibition } & With satisfaction & 52 & 41.93 & \multirow[t]{2}{*}{802.5} & \multirow[t]{2}{*}{-3.085} & \multirow[t]{2}{*}{0.002} \\
\hline & $\begin{array}{l}\text { Without } \\
\text { satisfaction }\end{array}$ & 48 & 59.78 & & & \\
\hline
\end{tabular}

According to the tables, significance level for all schemas except for sacrifice and unrelenting standards was less than 0.05. Therefore, all Schemas except Schema of sacrifice and unrelenting standards in women without marital satisfaction are different from women with marital satisfaction so that women without marital satisfaction have more EMS than women with marital satisfaction.

Table 3 independent $t$ test to compare Means of Emotional schemas in women with marital satisfaction and without marital satisfaction

\begin{tabular}{|c|c|c|c|c|c|c|c|c|}
\hline & & \multirow[t]{2}{*}{ Mean } & \multirow{2}{*}{$\begin{array}{l}\text { Standard } \\
\text { deviation }\end{array}$} & \multicolumn{2}{|c|}{ Levin test } & \multirow[t]{2}{*}{$\mathbf{T}$} & \multirow{2}{*}{$\begin{array}{l}\text { Degree } \\
\text { of } \\
\text { freedom }\end{array}$} & \multirow{2}{*}{$\begin{array}{l}\text { Significance } \\
\text { level }\end{array}$} \\
\hline & & & & $\mathbf{F}$ & $\begin{array}{l}\text { Significance } \\
\text { level }\end{array}$ & & & \\
\hline \multirow[t]{2}{*}{ Rumination } & $\begin{array}{l}\text { With } \\
\text { satisfaction }\end{array}$ & 6.96 & 2.737 & \multirow[t]{2}{*}{0.002} & \multirow[t]{2}{*}{0.965} & \multirow[t]{2}{*}{-1.351} & \multirow[t]{2}{*}{-1.351} & \multirow[t]{2}{*}{0.180} \\
\hline & $\begin{array}{l}\text { Without } \\
\text { satisfaction }\end{array}$ & 7.71 & 2.790 & & & & & \\
\hline \multirow[t]{2}{*}{ Guilt } & $\begin{array}{l}\text { With } \\
\text { satisfaction }\end{array}$ & 5.58 & 2.674 & \multirow[t]{2}{*}{0.283} & \multirow[t]{2}{*}{0.596} & -.290 & 98 & 0.772 \\
\hline & $\begin{array}{l}\text { Without } \\
\text { satisfaction }\end{array}$ & 5.73 & 2.558 & & & & & \\
\hline \multirow[t]{2}{*}{ Control } & $\begin{array}{l}\text { With } \\
\text { satisfaction }\end{array}$ & 3.38 & 2.410 & 0.496 & 0.483 & -3.020 & 98 & 0.003 \\
\hline & $\begin{array}{l}\text { Without } \\
\text { satisfaction }\end{array}$ & 4.96 & 2.798 & & & & & \\
\hline \multirow[t]{2}{*}{ Blame } & $\begin{array}{l}\text { With } \\
\text { satisfaction }\end{array}$ & 3.83 & 2.046 & 5.331 & 0.023 & -3.206 & 98 & 0.002 \\
\hline & $\begin{array}{l}\text { Without } \\
\text { satisfaction }\end{array}$ & 5.00 & 1.557 & & & & & \\
\hline
\end{tabular}




\begin{tabular}{|c|c|c|c|c|c|c|c|c|}
\hline \multirow[t]{2}{*}{ Rational } & $\begin{array}{l}\text { With } \\
\text { satisfaction }\end{array}$ & 10.87 & 3.100 & 0.385 & 0.536 & 0.215 & 98 & 0.831 \\
\hline & $\begin{array}{l}\text { Without } \\
\text { satisfaction }\end{array}$ & 10.73 & 3.247 & & & & & \\
\hline \multirow[t]{2}{*}{ Numbness } & $\begin{array}{l}\text { With } \\
\text { satisfaction }\end{array}$ & 5.38 & 1.623 & 0.197 & 0.658 & 1.338 & 98 & 0.184 \\
\hline & $\begin{array}{l}\text { Without } \\
\text { satisfaction }\end{array}$ & 4.94 & 1.719 & & & & & \\
\hline \multirow[t]{2}{*}{$\begin{array}{l}\text { Acceptance } \\
\text { of feelings }\end{array}$} & $\begin{array}{l}\text { With } \\
\text { satisfaction }\end{array}$ & 7.54 & 2.429 & 2.835 & 0.095 & 2.441 & 98 & 0.016 \\
\hline & $\begin{array}{l}\text { Without } \\
\text { satisfaction }\end{array}$ & 6.46 & 1.946 & & & & & \\
\hline
\end{tabular}

Table 4 Mann-Whitney for Comparing means of emotional schemas in women with marital satisfaction and non-marital satisfaction

\begin{tabular}{|c|c|c|c|c|c|c|}
\hline & Group & Frequency & Mean & $\begin{array}{l}\text { U Mann } \\
\text { Whitney }\end{array}$ & Statistics & $\begin{array}{l}\text { Significance } \\
\text { level }\end{array}$ \\
\hline \multirow{2}{*}{$\begin{array}{l}\text { Simplistic view of } \\
\text { emotion }\end{array}$} & With satisfaction & 52 & 52 & \multirow[t]{2}{*}{824} & \multirow[t]{2}{*}{-2.984} & \multirow[t]{2}{*}{0.003} \\
\hline & $\begin{array}{l}\text { Without } \\
\text { satisfaction }\end{array}$ & 48 & 48 & & & \\
\hline \multirow[t]{2}{*}{ Expression } & With satisfaction & 52 & 52 & \multirow[t]{2}{*}{1195} & \multirow[t]{2}{*}{-0.375} & \multirow[t]{2}{*}{0.708} \\
\hline & $\begin{array}{l}\text { Without } \\
\text { satisfaction }\end{array}$ & 48 & 48 & & & \\
\hline \multirow[t]{2}{*}{ Validation } & With satisfaction & 52 & 52 & \multirow[t]{2}{*}{716.5} & \multirow[t]{2}{*}{-3.734} & \multirow[t]{2}{*}{0.000} \\
\hline & $\begin{array}{l}\text { Without } \\
\text { satisfaction }\end{array}$ & 48 & 48 & & & \\
\hline \multirow[t]{2}{*}{ comprehensibility } & With satisfaction & 52 & 52 & \multirow[t]{2}{*}{940} & \multirow[t]{2}{*}{-2.144} & \multirow[t]{2}{*}{0.032} \\
\hline & $\begin{array}{l}\text { Without } \\
\text { satisfaction }\end{array}$ & 48 & 48 & & & \\
\hline \multirow[t]{2}{*}{ Higher values } & With satisfaction & 52 & 52 & \multirow[t]{2}{*}{833.5} & \multirow[t]{2}{*}{-2.540} & \multirow[t]{2}{*}{0.011} \\
\hline & $\begin{array}{l}\text { Without } \\
\text { satisfaction }\end{array}$ & 48 & 48 & & & \\
\hline \multirow[t]{2}{*}{ Consensus } & With satisfaction & 52 & 52 & \multirow[t]{2}{*}{1107} & \multirow[t]{2}{*}{-0.986} & \multirow[t]{2}{*}{0.324} \\
\hline & $\begin{array}{l}\text { Without } \\
\text { satisfaction }\end{array}$ & 48 & 48 & & & \\
\hline
\end{tabular}

The results showed there is a difference between women with marital satisfaction and without marital satisfaction in schemas of control, blame, Simplistic view of emotion, acceptance of feelings, validation, comprehensibility and higher values in such a way that the schemas control, blame and Simplistic view of emotion in women without marital satisfaction were more and schemas of acceptance of feelings, validation, comprehensibility and higher values were seen more in women with marital satisfaction. To examine the predictive power of cognitive and emotional schemas on marital satisfaction regression model was conducted. 
Table 5 Coefficients for determining the linear regression equation

\begin{tabular}{|c|c|c|c|c|c|}
\hline \multicolumn{6}{|l|}{ Coefficients } \\
\hline \multirow[t]{2}{*}{ Model } & \multirow{2}{*}{\begin{tabular}{|l|}
$\begin{array}{l}\text { Standardized } \\
\text { coefficients }\end{array}$ \\
Beta coefficient
\end{tabular}} & \multicolumn{2}{|c|}{$\begin{array}{l}\text { unstandardized } \\
\text { coefficients }\end{array}$} & \multirow[t]{2}{*}{$\mathbf{T}$} & \multirow[t]{2}{*}{$\begin{array}{l}\text { Significance } \\
\text { level }\end{array}$} \\
\hline & & $\begin{array}{l}\text { Standard } \\
\text { deviation error }\end{array}$ & B & & \\
\hline Fixed & .000 & 15.086 & 19.947 & 1.322 & \\
\hline Emotional deprivation & .002 & -3.220 & -0.231 & 0.072 & -0.385 \\
\hline Abandonment & .980 & .026 & 0.002 & 0.072 & 0.003 \\
\hline Mistrust & .977 & -.029 & -0.002 & 0.078 & -0.003 \\
\hline Social isolation & .321 & .999 & 0.105 & 0.105 & 0.127 \\
\hline Defectiveness/shame & .255 & 1.146 & 0.186 & 0.162 & 0.177 \\
\hline Failure & .333 & -.975 & -0.092 & 0.094 & -0.122 \\
\hline Dependence & .516 & -.652 & -0.067 & 0.102 & -0.082 \\
\hline Vulnerability & .994 & .008 & 0.001 & 0.100 & 0.001 \\
\hline Involved & .085 & -1.742 & -0.123 & 0.070 & -0.184 \\
\hline Subjugation & .164 & -1.405 & -0.113 & 0.080 & -0.198 \\
\hline Self-sacrifice & .897 & .130 & 0.008 & 0.065 & 0.014 \\
\hline Emotional inhabitation & .132 & -1.522 & -0.105 & 0.069 & -0.183 \\
\hline Unrelenting standards & .020 & 2.376 & 0.165 & 0.070 & 0.272 \\
\hline Entitlement & .537 & -.620 & -0.049 & 0.079 & -0.072 \\
\hline Hyper criticalness & .953 & .060 & 0.004 & 0.070 & 0.006 \\
\hline Rumination & .434 & .787 & 0.098 & 0.124 & 0.087 \\
\hline Comprehensibility & .281 & -1.085 & -0.182 & 0.168 & 0.168 \\
\hline Guilt & .032 & 2.181 & 0.281 & 0.129 & 0.234 \\
\hline Emotion expression & .531 & -.629 & -0.121 & 0.192 & 0.062 \\
\hline Control & .113 & -1.602 & -0.208 & 0.130 & -0.181 \\
\hline Blame & .000 & 3.983 & 0.680 & 0.171 & 0.404 \\
\hline Rational & .227 & 1.217 & 0.154 & 0.127 & 0.131 \\
\hline Higher values & .092 & -1.704 & 0.314 & 0.184 & -0.192 \\
\hline Acceptance of feelings & .931 & .87 & 0.010 & 0.110 & 0.010 \\
\hline Consensus & .755 & -.314 & -0.059 & 0.189 & -0.032 \\
\hline
\end{tabular}

Among the schemas, the schemas of abandonment and unrelenting standards and guilt and can predict marital satisfaction, respectively.

In the Simultaneous regression model cognitive and emotion schemas among all the schemas, just schema of guilt and blame from emotional deprivation and emotional schemas and Unrelenting Standards from cognitive schemas simultaneously were associated with marital satisfaction. 
Marital satisfaction $=150879+0.289$ (guilt) +0.33 (blame) -0.227 (emotional deprivation) +0.167 (Unrelenting Standards)

The results of analysis of variance showed no significant difference between demographic variables (age, education and occupation) in groups of with and without marital satisfaction.

\section{Conclusion}

The results showed that early maladaptive schemas except sacrifice and unrelenting standards in women without marital satisfaction is different from women with marital satisfaction. Early maladaptive schemas in women without marital satisfaction was more than women with marital satisfaction. Sacrifice and unrelenting standards exist in a large number of women. Results of this study showed 45 percent of women have the Schema of unrelenting standards and 32 percent have sacrifice schema. There were no significant differences between sacrifice and unrelenting standards in satisfied/dissatisfied women, maybe the cultural and values conditions within the community cause this result. These findings are consistent with the results of Yousef nejad shirvani,2011[23].He showed a significant negative relationship between early maladaptive schemas (emotional deprivation, social isolation, defectiveness / shame, failure, dependence / incompetence, vulnerability to harm or illness, Subjugation, emotional inhibition, unrelenting standards, selfdiscipline and Insufficient Self-Control) and life satisfaction of students. Epstein, Lipson, Holstein and Huh (1992) showed unrelenting standards and sacrifice are the deepest cognitive element predictor of compatibility and incompatibility in couples [24]. That is somewhat inconsistent with our findings it may be due to cultural differences of the two communities.

The results showed significant difference between women without marital satisfaction and women with marital satisfaction in emotional schemas. Control, blame, comprehensibility, Higher values, Simplistic view of emotion, validation, acceptance of feelings were significantly different and Control, blame, simplistic view of emotions were more frequent in dissatisfied women and acceptance of feelings, higher values, comprehensibility and validation seen more in women with marital satisfaction. The results of Pirsaghi, Mohammad Nazari, Naimi, Shafayi, (2014), Daneshmandi, Izadkhah, Kazemi and Mehrabi (2013), Hassani et al (2013) also were consistent with our findings in the field of emotional schemas $[14,25,26]$. As mentioned in these studies, individuals have suppressed emotion in the field of abandonment in her past that experience this emotion abusive in interpersonal relations and modify the natural history of marital satisfaction and its satisfaction.

Till now we didn't found any research that had studied the role of cognitive and emotional schemas simultaneously with marital satisfaction. However, findings of this study is consistent with results of other researches $[27,23,2,15,28-30]$.

Cognitive and emotional schemas explained $21.7 \%$ of the variances of marital satisfaction. Emotional deprivation and unrelenting standards schemas among the cognitive schemas and guilt and blame among the emotional schemas can predict likelihood of marital dissatisfaction. The findings show that there was cognitive pattern in individuals with low satisfaction that the main core of this cognitive pattern is abandoned by the other. As the above description suggests, one of the infrastructures of sexual satisfaction, security and sense of protection and connection are not included in this individuals and dissatisfaction in women are predictable with such schemas [31]. Blame indicate to self-incrimination and incriminating others. In emotion focused therapy, blaming lead to depression and anxiety which is related to marital conflict [10] and when people found that their feelings and emotions are different from others sense of guilt will appear and they will wrap their emotions and it lead to marital conflict [10].

Unrelenting standards /Hyper criticalness often lead to serious defects in feelings of pleasure, relaxation, health, selfworth, or progress is satisfied relation with others. Individuals with this schema believe they must work hard to achieve their ambitious standards and they do so to avoid disapproval or embarrassment. This schema usually leads to extreme reproach of themselves and others. This condition is known as a maladaptive schema that lead to health problems, selfworth, interpersonal relations or enjoy life [32].

In conclusion the formation and development of some schemas or structures during life can influence various aspects of marital life. So that these schemas have an important role for the evaluation of our emotional partner and attitude towards him. In general schema theory emphasize on the formation of this structure since its early life that will last into adulthood and it would have an impact on romantic relationship in couples and marital satisfaction [27].

In this research there were some limitations; Lack of adequate resources in emotional schemas specially translated resources was a main problem, which was time consuming to translate and collect material. The findings of this study relate to married women in Tehran; Therefore, in generalizing the results to other cities and provinces should be treated 
conservatively. No direct supervising on the process of questionnaire completion cause removal of a large number of questionnaires.

To evaluate the structure relationships of variables is recommended. Using more accurate diagnostic tools such as interviews in diagnosis of marital satisfaction would be advised.

This article has been adopted from master's thesis in clinical psychology in the University of Tehran Sciences and Research Branch.

\section{Compliance with ethical standards}

\section{Acknowledgments}

The authors would like to acknowledge the contributions of women who have completed questionnaires of this research.

\section{Disclosure of conflict of interest}

Study design: Z.P and N. A. Data synthesis: E. E. Drafting the manuscript: N.A and E.E. Critical revision of the manuscript: Z.P and N.A. Revision of manuscript: N.A.

The authors declare that they have no competing interests.

\section{Statement of informed consent}

Informed consent was obtained from all individual participants included in the study.

\section{References}

[1] Sprecher.S, Wenzel.A, \& Harvey.J. H,andbook of Relationship Initiation. New York: Taylor\& Francis Group. 2008.

[2] Yousefi, R Abedin, A, Tirgar, A \& Fathabadi, J. The effectiveness of educational interventions based on schemas model in promoting marital satisfaction. Journal of Clinical Psychology. second year. 2010; (3) (7):25-37.

[3] Halford, Dk. Short-term couple therapy. Translated by MostafaTabrizi, MojdeKardani and ForoughJafari. Tehran: Fara ravan publiction. 2005.

[4] Rosen-Grandon.JR, Myers.JE, Hattie.JA. The relationship between marital characteristics, marital interaction processes and marital satisfaction. J Couns \& Dev. 2004; 82 (1):58-68.

[5] Epstein, NB, \& Baucom.DH. Enhanced cognitive behavioural therapy for couples: A contextual approach. Washington DC: American Psychological Association. 2002; P. 284.

[6] Leahy R L. Emotional schemas in cognitive therapy. Paper presented at the annual meeting of the Association for Advancement of Behavior Therapy, Philadelphia, PA. 2001.

[7] Leahy, R L. Emotional Schemas and resistance to change in anxiety disorders. Cognitive and behavioral practice, 2007; 14:36-45.

[8] Leahy, R L. Emotional schemas and resistance to change in anxiety disorders in D. Sookman \& R L Leahy (Ed.), Treatment resistant anxiety disorders. 2010; pp. 135-160. New York: Routledge.

[9] Garnefski N, Van-Der-Kommer T, Kraaij V, Teerds J, Legerstee J,. \& Tein EO. The Relationship between Cognitive Emotion Regulation Strategies and Emotional Problems: Comparison between a Clinical and a Non-Clinical Sample. Eur J Per, 2002; 16:403-20.

[10] Leahy, R L. Model of emotional schemas. Cogn and Behav Pract. 2002; (9):177-190 .

[11] Leahy, R L, Tirch, D, \& Napolitano, L A Emotion regulation in psychotherapy: A practitioner's guide. New York: Guilford Press. 2011.

[12] Leahy, R L, \& Kaplan, D Emotional schemas and relationship adjustment. Paper presented at the meeting of the Association for Advancement of Behavior Therapy, New Orleans, LA 2004. 
[13] Marshall, A D, Panuzio, J, Makin-Byrd, K N, Taft, C T \& Holtzworth-Munroe, A 2011. A multilevel examination of interpartner intimate partner violence and psychological aggression reporting concordance. Behavio Therapy. Advance online publication. doi:10.1016/j.beth.2010.09.003.

[14] Pirsaghi, p Mohammad Nazari, Ali.Naimi, Gh. Shafei, d. Marital conflict, role emotional and schema defensive style. Iranian Journal of Nursing Science. 2014; 3 (1):59-69.

[15] Hasanvand, p .Davoudi, a, \&. Valizadeh, M. Early maladaptive schemas and aggressive relationship with marital satisfaction.Journal of Contemporary Psychology. 2009; 5:272-274.

[16] Anastasi, A. Psychometric assessment. Translated by Mohammad Naghi Baraheni. Tehran: Tehran University Press. 2007.

[17] Young, JE. Young Schema Questionnaire-Short Form. New York: Schema Therapy Institute. 2005.

[18] Schmidt, NB, Joiner, TE, Young, JE, \& Telch, MJ. The Schema Questionnaire: Investigation of psychometric properties and the hierarchical structure of a measure of maladaptive schema. Cognitive Therapy and Research, 1995; 19 (3):295-321.

[19] Aahi, gh. Standardization short version of the Young Schema Questionnaire .Master's Thesis in Psychology, Tehran, Allameh Tabatabaei University. 2005.

[20] Khanzadeh, d Edrisi, p Mohammad Khani, \& n Saeidian, M. Factor structure and psychometric characteristics on students' emotional schemas scale. Journal of Clinical Psychology. 2011; 6, 3:91-119.

[21] Soleimanian, a.Effect of irrational Belief (based on cognitive approach) on marital satisfaction. Master's thesis. Tehran: Teacher Training University. 1994.

[22] Mahdavian.F. Effect of communication training on marital satisfaction and mental health. Master's thesis. Tehran: Psychiatric Institute. 1996.

[23] Yousef nejad Shirvani, M.The relationship between life satisfaction and early maladaptive schemas students. Journal of Applied Psychology and research. 2010; 12, 2:55-65.

[24] Epstein, S, Lipson, A, Holstein, C, \& Huh, E. Irrational reactions to negative outcomes: Evidence for two conceptual systems. Journal of Personality and Social Psychology, 62, 328-339. Family functioning. Journal of Marital and Family Therapy, 1992; 35 (3):303-316.

[25] Daneshmandi, S Izadkhah, g. Kazemi, H, \& Mehrabi, H. Effectiveness of emotional schemas of emotional schemas women victims of child abuse and neglect. Journal of Medical Sciences, 2013; 22 (5):1481-1494.

[26] Hassani, J Taj al-Din, a GhaedniayJahromy, \& FarmaniShahrReza, n Compare cognitive emotion regulation strategies and emotional schemas in spouses of patients with substance abuse and normal individuals. Journal of Clinical Psychology.Sixth year. 2013; (1) 21:91-101.

[27] Bashiri Nakhlestani, E. Early maladaptive schemas investigate the relationship between attachment styles and marital satisfaction. Master's thesis. EmamKhomeini International University.Ghazvin. 2012.

[28] Zolfaghari, M. The relationship between early maladaptive schemas with dimensions of marital intimacy. Journal of Family Research. 2007; (4) 3:261-247.

[29] Anduz, Z \& Hamidpour H. The relationship between early maladaptive schemas, attachment style and marital satisfaction in couples. Proceedings of the Second Congress of Pathology in Iran. Tehran Shahid Beheshti University, 2005.

[30] Welburn, K, Coristine, M, Dagg, P, Pontefract, A, \& Jordan, S. The Schema Questionnaire- Short Form: Factor analysis and relationship between schemas and symptoms. Journal of Cognitive Therapy and Research, 2002; 26 (4):519-530.

[31] Manzary L, Makvandi, B, Khajevand Khoshli A. Comparison between maladaptive schemas, marital conflicts and sexual satisfaction in nearly divorced, divorced and normal individuals. Journal of psychology and behavioral studies, 2014; 12 (2):39-49.

[32] Young, J 0; Kolsko, n; \& vishar, d. Schema Therapy (Practical Guide for Clinicians. Translated by Hassan Hamidpour, Zahra Anduz. Tehran: Arjmand Pub. 2006. 